\title{
Application of Comet assay to assess the effects of white bean meal on DNA of human lymphocytes
}

\author{
Luciana Lopes Silva Pereira, ${ }^{1, *}$, Silvana Marcussi ${ }^{1}$, Lívia Cabral Sátiro ${ }^{1}$, Chrystian Araujo Pereira ${ }^{2}$, \\ Larissa Fonseca Andrade ${ }^{3}$, Lisete Chamma Davide ${ }^{4}$, Custódio Donizete dos Santos ${ }^{1}$
}

\begin{abstract}
${ }^{1}$ Department of Chemistry, Federal University of Lavras, ${ }^{2}$ Department of Biochemistry, Federal University of Triangulo Mineiro, ${ }^{3}$ Department of Plant Production, Federal University of Espirito Santo, ${ }^{4}$ Department of Biology, Federal University of Lavras
\end{abstract}

\begin{abstract}
This study was conducted to evaluate the potential induction of genotoxic effects of white bean flour using the Comet assay. The test was conducted with human lymphocytes present in whole blood immediately after collection, by incubation with white bean flour in three concentrations (3.92, 9.52 and $18.18 \mathrm{mg} /$ $\mathrm{mL}$ ) at $37{ }^{\circ} \mathrm{C}$ for $4 \mathrm{~h}$ followed by preparation of slides. Samples were considered positive (above $20 \%$ damage) when the damage observed to cellular DNA was higher than the negative control. No genotoxic potential was found at the doses tested. However, it would be premature to suggest absence of risk to human health of DNA damage since the exposure of cells to the extract was restricted to four hours rather than a whole cell cycle. Additionally, further information on toxicology should be obtained in future studies.
\end{abstract}

Uniterms: Genotoxicity. White bean flour/genotoxic effects. Comet assay/toxicological analysis of food. Food/toxicological analysis.

\begin{abstract}
Este estudo foi realizado para avaliar o potencial de indução de efeitos genotóxicos da farinha de feijão branco utilizando o teste do Cometa. O ensaio foi realizado com linfócitos humanos presentes no sangue imediatamente após a coleta, por incubação com farinha de feijão branco em três concentrações $(3,92$, 9,52 e $18,18 \mathrm{mg} / \mathrm{mL}$ ) a $37^{\circ} \mathrm{C}$ por $4 \mathrm{~h}$, seguida de preparação das lâminas. As amostras foram consideradas positivas (acima de $20 \%$ de dano), quando os danos observados no DNA celular foram maiores do que o controle negativo. Verificou-se que as doses testadas não mostraram potencial genotóxico. No entanto, seria prematuro fazer recomendações sobre o padrão de riscos para a saúde humana resultantes de danos ao DNA já que exposição das células ao extrato foi restrito ao período de quatro horas e não durante um ciclo celular completo. Além disso, outras informações sobre a toxicologia devem ser obtidas no futuro.
\end{abstract}

Unitermos: Genotoxicidade. Farinha de feijão branco/efeitos genotóxicos. Teste do Cometa/análise toxicológica de alimentos. Alimentos/análise toxicológica.

\section{INTRODUCTION}

The need for new drugs has driven the search for molecules that act as enzyme inhibitors and for substrates or inhibitors that bind selectively to the enzymes. The protein inhibitors of $\alpha$-amylase (1-4 $\alpha$-D-glucan glucanohydrolase, EC 3.2.1.1) are widely distributed in plants, particularly cereals (wheat and barley) and beans. This inhibition induces carbohydrate tolerance, satiety, weight loss and prolonged gastric emptying, which may be use-

*Correspondence: L. L. S. Pereira. Departamento de Química, Universidade Federal de Lavras, Campus Universitário - CP 3037 - 37200-000 - Lavras - MG, Brasil. E-mail: lucianalsp@yahoo.com.br ful in treating obesity and non-insulin-dependent diabetes mellitus (Chen et al., 2008). The daily use of white bean flour has become increasingly common, given the presence of the $\alpha$-amylase inhibitor known as phaseolamine. However, studies have shown the presence of antinutritional factors in the raw bean to be important (Pereira et al., 2009). Therefore, doubts remain over the viability of using raw bean flour considering both health benefits and drawbacks.

Living organisms have a genome that is subject to the constant action of exogenous or endogenous agents that can affect the chemical integrity of DNA by altering the information contained therein. Different changes are responsible for genomic instability, and play an important 
role in carcinogenesis (Jefford, Irminger-Finger, 2006). Thus, mutations can arise in genes that control synthesis and DNA repair, the cell cycle or apoptosis, leading to increased basal mutation rate, which satisfactorily explains the fact that there are multiple mutations in tumors (Sarasin, 2003).

Chromosomal aberrations, sister chromatid exchange and micronucleus formation in human peripheral blood lymphocytes have been considered as biomarkers of exposure to genotoxic changes and carcinogenic agents. Some researchers hold that the underlying mechanisms of DNA damage are similar in different tissues, thus suggesting that damage levels in lymphocytes may reflect those occurring in other tissues (Albertini et al., 2000; Norppa, 1997).

For a product to be recommended as a food and/or drug, its biological properties must be well elucidated. Numbering among the tests recommended by the Food and Drug Administration (FDA), are those related to mutagenic and antimutagenic properties (FDA, 2001).

Genetic Toxicology is an area that covers mainly the study of mutagenicity, carcinogenicity and teratogenicity. In this area there are several tests for biomonitoring, genotoxicity and mutagenesis and one such test used to evaluate mutagenic potential is Comet. This test constitutes a simple, rapid, sensitive and inexpensive assay for detecting DNA damage (Tice et al., 2000). The Comet assay is used to detect mutations but also verifies genomic lesions that, after processing, can result in mutation. Unlike mutations, lesions detected by comet assay are subject to correction. Thus, the test can also be used for studies of DNA repair, providing important information on the kinetics and type of lesion repaired, although is unable to infer the reliability of the repair process (Albertini et al., 2000). The technique entails the immersion of viable cells in agarose, lysing the cell membrane by detergents and alkaline salts, and subsequent electrophoresis. With electrophoresis under alkaline conditions, cells with damaged DNA have a higher rate of migration toward the anode due to single strand breaks or alkali labile sites, double simulating the appearance of a comet (head and tail) (Pavão et al., 2007).

For white bean flour, application of the Comet assay will assess whether the recommended dose for human consumption would be likely to induce DNA damage after short time exposure of blood cells.

Moreover, there is currently no data available in the literature related to research on the mutagenicity of white bean flour. In this context, the aim of the present work was to verify the possible induction of DNA damage in human cells by the Comet test.

\section{MATERIAL AND METHODS}

\section{Preparation of white bean flour (WBF)}

The white beans were cultivated in Campo Belo, Minas Gerais state, and purchased from a local supermarket. The beans with coat were washed with distilled water and dried in an oven with air circulation at $30^{\circ} \mathrm{C}$ until constant weight. To obtain the flour (WBF), the grains were crushed in a hand mill followed by a knife mill (TE Tecnal 631) to obtain a smaller particle size.

WBF homogenate at a concentration of $0.2 \mathrm{~g} / \mathrm{mL}$ was prepared in a laminar flow chamber using sterile buffer PBS (Phosphate Buffer Saline).

\section{Preparation of treatments}

Peripheral blood from five volunteers aged between 21 and 40 years, without overt signs or symptoms of disease was used after informed consent. Smokers or subjects occupationally exposed to environmental contaminants (pesticides, paints, etc.) and those in continuous use medication were excluded from the sample. Blood was collected under vacuum and protected from light immediately after collection. Subsequently, different volumes of WBF homogenate were added to aliquots of $500 \mu \mathrm{L}$ of blood to obtain samples with increasing concentrations of WBF (3.92, 9.52 and $18.18 \mathrm{mg} / \mathrm{mL}$ blood). In addition to the samples, negative $(500 \mu \mathrm{L}$ of blood $)$ and positive (doxorubicin $18.0 \mathrm{mg} / \mathrm{mL}$ of blood) controls were prepared. Doxorubicin is an antitumoral family of anthracyclines, which can cause DNA damage and thus is widely used as a control in the comet assay being known to induce damage at level 3 and 4 in DNA of animal cells (Barcelos et al., 2009).

All procedures were performed in a laminar flow chamber under light. Finally, mixtures of blood with different treatments were incubated for 4 hours at $37^{\circ} \mathrm{C}$. Comet assays were performed shortly after this period.

\section{The Comet assay}

The comet assay was performed according to the methodology described by TICE et al. (2000), with modifications. The slides were previously covered by agarose solution of normal melting point (NMP) $1 \%$. This layer was used to promote adhesion of agarose of low melting point (LMP) containing cells. For this purpose, an aliquot $(5 \mu \mathrm{L})$ of each cell suspension was mixed with the treatments of $100 \mu \mathrm{L}$ of LMP agarose and dripped onto the slide, covered with coverslip $(24 \times 60 \mathrm{~mm})$ and kept at a low 
temperature $\left( \pm 4^{\circ} \mathrm{C}\right)$ for $5 \mathrm{~min}$, until solidification of the gel. The coverslip was then removed and slides immersed in lysis solution $(2.5 \mathrm{M} \mathrm{NaCl}, 100 \mathrm{mM}$ EDTA, $10 \mathrm{mM}$ Tris, $1 \%$ Triton $\mathrm{X}-100,10 \% \mathrm{DMSO}, \mathrm{pH} 10$ ) and protected from light, where they remained for $24 \mathrm{~h}$ at $4{ }^{\circ} \mathrm{C}$. After this period, the slides were transferred to a vat containing electrophoresis solution ( $1 \mathrm{mM}$ EDTA, $300 \mathrm{mM} \mathrm{NaOH}$, $\mathrm{pH}$ 13), left in the refrigerator for 20 minutes and then placed in a horizontal electrophoresis system. The horizontal electrophoresis system was filled with the freshly prepared electrophoresis solution at a higher level $(0.25 \mathrm{~cm}$ on average) than the slides. These were at static for $20 \mathrm{~min}$ to allow DNA unwinding, relaxation of their links and exposure of alkali-labile sites. The electrophoresis was performed at $4{ }^{\circ} \mathrm{C}$ with $25 \mathrm{~V}$ and $300 \mathrm{~mA}$ for $30 \mathrm{~min}$. The slides were subsequently removed from the electrophoresis system, submerged in neutralization buffer $(0.4 \mathrm{M}$ Tris, $\mathrm{pH} 7.5$ ) for $15 \mathrm{~min}$ until completely dry and fixed with $100 \%$ ethanol for 3 minutes. Slides were then stained with propidium iodide at a final concentration of $2.5 \mathrm{mg} / \mathrm{mL}$ using a volume of $50 \mu \mathrm{L}$, covered with coverslip and viewed under a Nikon ECLIPSE E400 fluorescence microscope. Images of 2000 randomly selected cells ( 400 cells from each treatment of five replicate slides). Cells were also visually scored according to tail size into five classes ranging from undamaged (0) to maximally damaged (4). The comets were classified according to extent of DNA damage into five categories: undamaged (damage $<5 \%$ ), low damage (5-20\%), medium level damage (20-40\%), high level of damage (40-85\%) and completely damaged (damage $>85 \%$ ). Damage levels recorded for each treat- ment were grouped into percentages. The frequency of damage (FD) was calculated based on the number of cells with comets, considering only damage above $20 \%$.

\section{Data analysis}

Results are expressed as means \pm S.D. and statistical significance was determined by one-way analysis of variance (ANOVA) using the software SISVAR (Ferreira, $2000)$. In all comparisons, $P<0.05$ was considered as indicating statistical significance.

\section{RESULTS AND DISCUSSION}

The amount of DNA breaks induced by white bean flour (WBF) at doses of 3.92, 9.52 and $18.18 \mathrm{mg} / \mathrm{mL}$ was statistically equal to the negative control (Table I) in all classes, thus revealing absence of genotoxicity at the concentrations used for 4-hour exposure of cells to treatment (Table I). There was a predominance of undamaged cells (class 0 ) and cells with minimal damage (class 1) at all concentrations tested (Table I).

Similar trials using the comet assay have been performed by several authors using extracts from various plants. One such study was conducted with extracts of Miconia sp, a kind of plant commonly used as an analgesic, antineoplastic remedy. Akin to the present study, the results showed a predominance of class 1 on the in vivo comet assay (Serpeloni et al., 2008).

Wan-Ibrahim et al. (2010) studied the effects of aqueous extracts of 20 plants in vitro and observed that

TABLE I - Average number of cells per comet class after treatment with different concentrations of aqueous solution of white bean flour $(\mathrm{WBF})$

\begin{tabular}{|c|c|c|c|c|c|}
\hline$\%$ Damage & Control (-) & Control $(+)^{*}$ & $\begin{array}{c}\text { WBF } \\
(3.92 \mu \mathrm{g} / \mathrm{mL})\end{array}$ & $\begin{array}{c}\text { WBF } \\
(9.52 \mu \mathrm{g} / \mathrm{mL})\end{array}$ & $\begin{array}{c}\text { WBF } \\
(18.18 \mu \mathrm{g} / \mathrm{mL})\end{array}$ \\
\hline $\begin{array}{l}\text { Class } 0 \\
(\text { damage }<5 \%)^{* *}\end{array}$ & $66.08 \mathrm{a}^{2}$ & $0.25 \mathrm{a}^{1}$ & $76.13 \mathrm{a}^{2}$ & $46.29 \mathrm{a}^{2}$ & $49.52 \mathrm{a}^{2}$ \\
\hline $\begin{array}{l}\text { Class } 1 \\
(\text { damage } 5-20 \%)^{* *}\end{array}$ & $31.20 \mathrm{~b}^{2}$ & $3.83 b^{1}$ & $23.42 b^{2}$ & $48.03 b^{2}$ & $36.37 b^{2}$ \\
\hline $\begin{array}{l}\text { Class } 3 \\
(\text { damage } 40-85 \%)^{* *}\end{array}$ & $0.00 \mathrm{~d}^{1}$ & $42.82 \mathrm{~d}^{2}$ & $0.00 \mathrm{~d}^{1}$ & $0.00 \mathrm{~d}^{1}$ & $3.68 \mathrm{~d}^{1}$ \\
\hline $\begin{array}{l}\text { Class } 4 \\
(\text { damage }>85 \%) * *\end{array}$ & $0.00 \mathrm{e}^{1}$ & $14.87 \mathrm{e}^{2}$ & $0.00 \mathrm{e}^{1}$ & $0.00 \mathrm{e}^{1}$ & $0.00 \mathrm{e}^{1}$ \\
\hline
\end{tabular}

The above results represent the mean values obtained in 3 or 4 blades. 100 nucleoids were analyzed in each slide, and 3-4 slides/treatment/volunteer. Five volunteers were involved (one volunteer/experiment). ${ }^{*}$ Positive control = doxorubicin $(\mathrm{DXR})$ $18.0 \mathrm{mg} / \mathrm{mL}$. ** Values with the same superscript letters do not differ at a level of 5\% significance on the Scot Knott test. 
only two caused greater than $50 \%$ damage to DNA, indicating severe damage. $V$. pinnata extracts were used in Southeast Asia for treatment of hypertension and $Q$. infectoria for its anti-free radical activity, given the high level of phenolic compounds, including tannins and gallic acid. The authors reported that tannic acid, a type of polyphenol soluble in water, can cause DNA damage in the presence of $\mathrm{Cu}$ (II). In contrast, there are reports that tannic acid can induce resistance against the DNA damage induced by food mutagens and $\mathrm{H}_{2} \mathrm{O}_{2}$. Given this paradox, a critical analysis of the cytotoxicity of metabolites of natural products must be conducted, taking into account the possible adverse effects that therapeutic plant extracts can cause and correlate them to dose and chronic use.

Other natural products such as Guaco (Mikania glomerata Spreng), espinheira santa (Maytenus ilicifolia Mart. Ex Reiss), açoita cavalo (Luehea divaricata Mart. Et. Zucc) and salvia (Lippia alba Mill. NE) have been shown to induce cytotoxic and genotoxic changes in vivo by constituents such as coumarins, tannins and terpenes present in large amounts (Strange et al., 2009).

The polyphenolic compounds in beans are primarily located in the seed coat and contain low or negligible amounts in the cotyledons. The differences in color between beans seem to influence the concentration of tannins in the grain. Some authors have reported higher levels of tannins in legumes compared with different colors of white beans (Silva, Silva, 1999). The white bean has a tannin content of about $33.38 \mathrm{mg} / 100 \mathrm{~g}$ beans, while in other cultivars, such as black beans (black diamond) and Carioca (pearl), the tannin content is 61.01 and $102.45 \mathrm{mg} / 100 \mathrm{~g}$ beans, respectively (Cárdenas et al., 2008). This lower concentration of tannin in white beans - despite the presence of other phenolic compounds including terpenes (saponins) and lectins (phytohemagglutinins) - could explain the results obtained in this work, i.e., the absence of toxic effects when measured by the Comet assay (Figure 1), under the experimental conditions.

A steady increase in the frequency of damage above $20 \%$ (damage level $\geq 2$ ) proportional to the concentration of WBF was observed (Figure 2). However, as shown in Table I, this increase is mainly observed in classes 1 and 2 with no significant increase in damage for classes 3 and 4 , as per positive control. Similar results were obtained by Santos et al. (2008) who, in a study assessing the genotoxic effect of aqueous extract of Physalis angulata L.(Solanaceae), reported a rise in frequency of comets with increasing doses of extract, with classes 1 and 2 the most frequently observed. The same was reported by Peres et al.(2009), in an assessment of cytotoxicity, mutagenicity

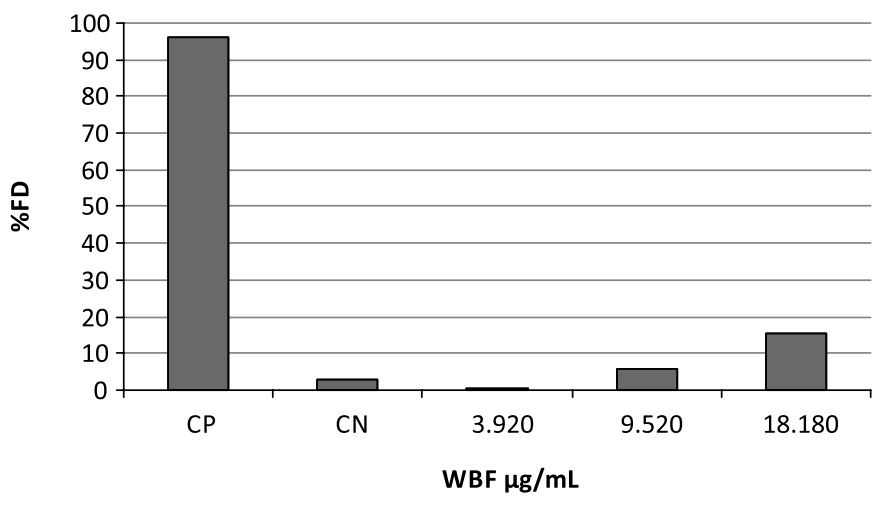

FIGURE 1 - Frequency of damage (FD) to DNA of human lymphocytes treated with different concentrations of WBF. Results expressed as percentage of FD in the nucleoid comet considering only $>20 \%$ damage (damage class $\geq 2$ ). $\mathrm{PC}$ : positive control = doxorubicin (DXR) $18.0 \mathrm{mg} / \mathrm{mL}$ and $\mathrm{NC}$ : negative control $=$ blood only without additions (values expressed as average of five replicates $\pm \mathrm{SD}$ ). Significant difference compared with positive control ( $* \mathrm{P}<0.01)$.

and genotoxicity of essential oil of Piper gaudichaudianum Kunth.

Therefore, the present results obtained from the comet assay suggest that the white bean flour cannot induce genotoxicity and mutagenicity in DNA. Nevertheless, these results cannot guarantee safety for therapeutic use, where the complementation of all stages of preclinical and clinical trials for various chronic experiments, plus in vivo tests at varying concentrations, are warranted.

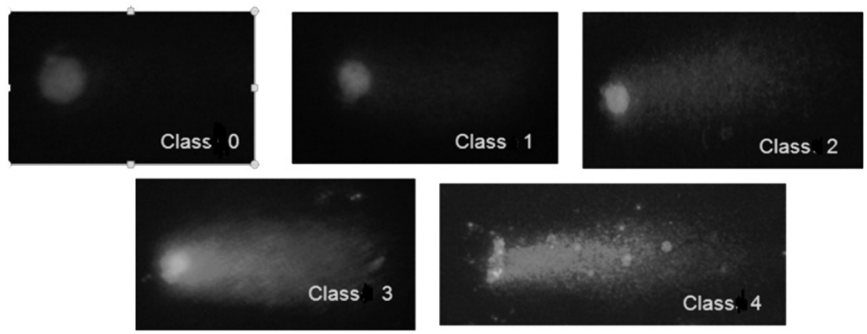

FIGURE 2 Photomicrographs of human lymphocyte nucleoid stained with propidium iodide. 200x magnification.

The toxicity of substances or extracts derived from plants represents a major issue in the validation of herbal medicine, which require evaluation in preclinical trials. The diversity of chemical compounds present in natural products calls for a thorough search of possible beneficial and/or deleterious biological actions.

Additional tests examining the chronic use of white bean flour are warranted to evaluate the possible occurrence of cumulative damage, since it is plausible that any such damage can be repaired resulting in no harm to cells. 


\section{CONCLUSIONS}

In conclusion, the absence or low frequency of class 3 and 4 comets suggests no genotoxic effects by WBF. However, doses tested were not genotoxic over the four hours cells were subjected to the presence of the treatments. Therefore, any safety recommendation would be premature, given that additional studies are needed to confirm efficacy, toxicity and safety.

\section{ACKNOWLEDGEMENT}

The authors are grateful to FAPEMIG for the financial support to the project and the doctoral scholarship.

\section{REFERENCES}

ALBERTINI, R.J.; ANDERSON, D.; DOUGLAS, G.R.; HAGMAR, L.; HEMMINKI K.K.; MERLO, F. IPCS guidelines for the monitoring of genotoxic effects of carcinogens in humans. Mutat. Res., v.463, n.2, p.111-172, 2000 .

BARCELOS, G.R.; ANGELI, J.P.; SERPELONI, J.M.; ROCHA, B.A.; MANTOVANI, M.S.; ANTUNES, L.M. Effect of annato on micronuclei induction by direct and indirect mutagens in HepG2 cells. Environ. Mol. Mutagen., v.50, n.9, p.808-814, 2009.

CÁRDENAS, L.R.; LEONEL, A.J.; COSTA, N.M.B. Efeito do processamento doméstico sobre o teor de nutrientes e de fatores antinutricionais de cultivares de feijão comum. Ciênc. Tecnol. Alim., v.28, n.1, p.200-213, 2008.

CHEN, X.; XU, G.; LI, X.; LI, Z.; YING, H. Purification of an $\alpha$-amylase inhibitor in a polyethylene glycol/fructose-1,6bisphosphate trisodium salt aqueous two-phase system. Process Biochem., v.43, n.7, p.765-768, 2008.

FERREIRA, D.F. Análises estatísticas por meio do SISVAR para Windows versão 4.0. In: REUNIÃO BRASILEIRA DA SOCIEDADE INTERNACIONAL DE BIOMETRIA, 45, 2000, São Carlos. Resumos. São Carlos: UFSCar, 2000. p. 235 .

FOOD AND DRUG ADMINISTRATION. U. S. Public Health Service, Department of health and human services, Public Health Service Food and Drug Administration College Park, MD 20740, 2001. Available at: <http://www.fda.gov/>. Accessed on: 19 aug. 2010.
JEFFORD, C.E.; IRMINGER-FINGER, I. Mechanisms of chromosome instability in cancers. Crit. Rev. Oncol. Hematol., v.59, n.1, p.1-14, 2006.

NORPPA, H. Cytogenetic markers of susceptibility: influence of polymorphic carcinogen-metabolizing enzymes. Environ. Health Perspect., v.105, n.8, p.829-835, 1997.

PAVÃO, P.R.G.; GONTIJO, A.M.M.C.; RIBEIRO, D.A.; SALVADORI, D.M.F. Ausência de efeito genotóxico induzido por esteróides anabolizantes em indivíduos fisiculturistas. Rev. Bras. Educ. Fís. Esp., v.21, n.1, p.5-10, 2007.

PEREIRA, L.L.S.; SANTOS, C.D.; CORRÊA, A.D.; SOUSA, R.V. Estudo comparativo entre inibidor de $\alpha$-amilase (Faseolamina) comercial e farinha de feijões branco, preto e carioca. Infarma, v.21, n.11/12, p.11-14, 2009.

PÉRES, V.F.; MOURA, D.J.; SPEROTTO, A.R.M.; DAMASCENO, F.C.; CARAMÃO, E.B.; ZINI, C.A.; SAFFI, J. Chemical composition and cytotoxic, mutagenic and genotoxic activities of the essential oil from Piper gaudichaudianum Kunth leaves. Food Chem. Toxicol., v.47, n.9, p.2389-2395, 2009.

SANTOS, R.A.; CABRAL, T.R.; CABRAL, I.R.; ANTUNES, L.M.; ANDRADE, C.P.; CARDOSO, P.C.S.; BAHIA, M.O.; PESSOA, C.; NASCIMENTO, J.L.M.; BURBANO, R.R.; TAKAHASHI, C.S. Genotoxic effect of Physalis angulata L. (Solanaceae) extract on human lymphocytes treated in vitro. Biocell, v.32, n.2, p.195-200, 2008.

SARASIN, A. An overview of the mechanisms of mutagenesis and carcinogenesis. Mutat. Res., v.544, n.2-3, p.99-106, 2003.

SERPELONI, J.M.; REIS, M.B.; RODRIGUES, J.; SANTOS, L.C.; VILEGAS, W.; VARANDA, E.A.; DOKKEDAL, A.L.; CÓLUS, I.M.S. In vivo assessment of DNA damage and protective effects of extracts from Miconia species using the comet assay and micronucleus test. Mutagenesis., v.23, n.6, p.501-507, 2008.

SILVA, M.R.; SILVA, M.A.A.P. Aspectos nutricionais de fitatos e taninos. Rev. Nutr., v.12, n.1, p.5-19, 1999. 
STRANGE, V.S.; GOMES, T.D.U.H.; ANDRADE, M.A.; BATITUCCI, M.C.P. Avaliação do efeito mutagênico do extrato hidroalcoólico bruto, por meio de bioensaios in vivo e prospecção fitoquímica de Cecropia glaziovii Sneth (embaúba), Cecropiaceae. Rev. Bras. Farmacog., v.19, n.2B, p.637-642, 2009.

TICE, R.R.; AGURELL, E.; ANDERSON, D.; BURLINSON, B.; HARTMANN, A.; KOBAYASHI, H.; IYAMAE, Y.; ROJAS, E.; RYU, J.C.; SASAKI, Y.F. Single cell gel/comet assay: guidelines for in vitro and in vivo genetic toxicology testing. Environ. Mol. Mutagen., v.35, n.3, p.206-221, 2000.
WAN-IBRAHIM, W.I.; SIDIK, K.; KUPPUSAMY, U.R. A high antioxidant level in edible plants is associated with genotoxic properties. Food Chem., v.122, n.4, p.1139-1144, 2010.

Received for publication on $26^{\text {th }}$ May 2011 Accepted for publication on $23^{\text {rd }}$ November 2011 